\title{
Effect of feed restriction on hepatic estradiol metabolism and liver function in cows
}

\author{
Mamiko ONO ${ }^{1) *}$, Tadatoshi OHTAKI ${ }^{2)}$, Toru NAKAHASHI') and \\ Shigehisa TSUMAGARI ${ }^{2)}$ \\ 1)Laboratory of Large Animal Clinical Sciences, Department of Veterinary Medicine, \\ College of Bioresource Sciences, Nihon University, Fujisawa, Kanagawa 252-0880, Japan \\ ${ }^{2)}$ Laboratory of Theriogenology, Department of Veterinary Medicine, College of Bioresource Sciences, \\ Nihon University, Fujisawa, Kanagawa 252-0880, Japan
}

\section{J. Vet. Med. Sci.}

81(12): 1873-1878, 2019

doi: $10.1292 /$ jvms.19-0178

Received: 28 March 2019

Accepted: 17 October 2019

Advanced Epub:

13 November 2019

\begin{abstract}
In this study, the effects of restriction feeding on the liver function, hepatic uridine diphosphate glucuronosyltransferase (UGT) activity, hepatic insulin-like growth factor (IGF)-1 mRNA expression and response to high-dose estradiol-17 $\left(\mathrm{E}_{2}\right)$ administration were investigated in non-lactating cows. Cows were assigned to either restricted feeding (30\% of total digestible nutrient requirement) or ad libitum feeding of a dent corn-based concentrate and roughage for a 2-week feeding trial (Day $1=$ day of beginning the feeding trial). On day 14 , a high-dose $E_{2}$ administration study was carried out to examine plasma $E_{2}$ levels as an indicator of hepatic $E_{2}$ metabolism. Plasma $E_{2}$ concentration in the restricted feeding group was consistently higher after high-dose $E_{2}$ administration than in the control group. In addition, indocyanine green half-life value was prolonged by restricted feeding for 13 days, and increased liver triglyceride concentration and decreased liver UGT activity were caused by this restriction over 14 days. Restricted feeding did not affect plasma IGF-1 concentration or hepatic IGF-1 mRNA expression. These results suggest that two weeks of restriction feeding led to accumulation of triglyceride, decreased liver blood flow, and slightly impaired liver function, which in turn slowed down the hepatic metabolism of $\mathrm{E}_{2}$ without significantly impacting hepatic IGF-1 production.
\end{abstract}

KEY WORDS: dry cow, estrogen metabolism, insulin-like growth factor (IGF)-1, restricted feeding, uridine diphosphate glucuronosyltransferase (UGT) activity

Sex steroid hormones are synthesized in the gonads and undergo metabolic transformations in the liver before being excreted into the urine and feces, except for a small fraction that is metabolized in the kidneys and intestine [3, 6]. The hepatic metabolism of these hormones has been studied in domestic animals. Parr et al. [13] found that the peripheral plasma progesterone $\left(\mathrm{P}_{4}\right)$ concentration is significantly influenced by the metabolic clearance rate in the liver of sheep. $\mathrm{P}_{4}$ concentration is also directly affected by postprandial blood flow from the gut to the liver in ovariectomized ewes [14]. Wieghart et al. [18] investigated the role of digestible energy intake in portal and hepatic vein blood flow rates, and their data showed that these blood flow rates decreased in dairy cows on high-concentrate and high-forage diets with restricted intake. Wiltbank et al. [20] found that, compared to non-lactating cows, lactating cows on high dry-matter intake had higher liver blood flow and 2.3 times greater hepatic metabolic rates of $\mathrm{P}_{4}$ and estrogen, resulting in lower circulating estrogen and $\mathrm{P}_{4}$ concentrations. This, they proposed, could lead to poor reproductive performance in the form of lower conception rates, pregnancy loss, multiple ovulation, or diminished signs of estrus. Collectively, these findings indicate the important role of feed intake in hepatic metabolism of sex hormones through its effect on liver blood flow. However, few studies are available regarding this theory for dairy cows. An in vitro assay has been established for the measurement of estradiol-17 $\beta\left(\mathrm{E}_{2}\right)$ glucuronidation activity by uridine diphosphate glucuronosyltransferase (UGT) using liver biopsy samples from dairy cows [4], but the level of UGT activity and its effect on circulating estrogen are not yet understood.

Insulin-like growth factor (IGF)-1 is produced mainly by the liver and greatly influenced by nutrition. In situations of high nutrient demand, such as during negative energy balance (NEB), the circulating IGF-1 concentrations are low. NEB partially controls the synthesis and secretion of IGF-1 from the liver [21]. In this study, we investigated the effect of two week-restriction feeding on hepatic estrogen metabolism (i.e. UGT activity), peripheral plasma insulin-like growth factor (IGF)-1 concentration, and hepatic IGF-1 mRNA expression. 


\section{MATERIALS AND METHODS}

\section{Animals}

Eight non-pregnant, dry Holstein cows (parity range, 1-5; $8.6 \pm 1.0$ years of age; average body weight, $675.0 \pm 26.8 \mathrm{~kg}$ ) kept at the Department of Veterinary Medicine, Nihon University were used for the study. The cows were tied in a stall during the study period and fed with dent corn silage, oats, beet pulp, and dicalcium phosphate according to the Japanese Feeding Standard for dairy cattle [7]. All procedures used in this experiment were approved by the Ethical Committee for Animal Experimentation at the College of Bioresource Sciences, Nihon University (NUBSV-157).

\section{Treatment}

Cows were allocated to a control group $(n=4)$ and restricted feeding group $(n=4)$. In the restricted feeding group, cows were on restricted feeding for two weeks from Day 1 to Day 14 according to Rhoads et al. [16] with modification. Briefly, the restricted feeding cows were fed $30 \%$ of the total digestible nutrient (TDN) requirement and $25 \%$ of dry matter intake (DM) with separate feeding, and control cows were fed $120 \%$ of TDN requirement and 100\% of DM with separate feeding. In all cows, feed was supplied twice a day at 9:00 and 15:00, and water was given ad libitum.

To synchronize the estrous cycle, all cows received $100 \mu \mathrm{g}$ of gonadotropin-releasing hormone (GnRH, fertirelin acetate; Conceral $^{\circledR}$, MSD Animal Health, Tokyo, Japan) intramuscularly and insertion of a controlled intravaginal drug-releasing device (CIDR, containing $1.9 \mathrm{~g}_{\text {of }} \mathrm{P}_{4}$; EAZI-BREED ${ }^{\mathrm{TM}} \mathrm{CIDR}^{\circledR}$, Livestock Improvement Association of Japan, Tokyo, Japan) into the vagina on Day 6. Seven days later, the CIDR was removed and $25 \mathrm{mg}$ of prostaglandin $\mathrm{F}_{2 \alpha}$ ( $\mathrm{PGF}_{2 \alpha}$, dinoprost, Pronalgon ${ }^{\circledR} \mathrm{F}$, Zoetis, Parsippany, NJ, U.S.A.) was administered intramuscularly. Then, a high-dose $\mathrm{E}_{2}$ administration study was performed at 2 days after CIDR removal and $\mathrm{PGF}_{2 \alpha}$ administration.

Body weight and body condition score (BCS) were measured every 2 days during the study period. Body weight was measured with an electronic scale (TRU-TEST EW5, Fujihira Industry, Tokyo, Japan), and BCS was measured according to Ferguson et al. [1].

\section{High-dose $E_{2}$ administration study}

High-dose $\mathrm{E}_{2}$ administration was carried out on Day 14 prior to feeding, as described by Sangsritavong et al. [17] with minor modification. Briefly, $\mathrm{E}_{2}$ ( $\beta$-Estradiol, Sigma-Aldrich, St. Louis, MO, U.S.A.) was dissolved in 99.8\% absolute ethanol (Wako Pure Chemical, Osaka, Japan) and diluted with physiological saline (Nippon Zenyaku Kogyo, Fukushima, Japan) to make a solution containing $3 \mu \mathrm{g} / \mathrm{m} l$ (w/v) $E_{2}$ and 1\% ethanol. A 14-G catheter (Nippon Zenyaku Kogyo) was placed into both jugular veins, connected with a butterfly needle, and flushed with physiological saline containing $25 \mathrm{IU} / \mathrm{m} l$ heparin. After an intravenous bolus injection of $10 \mathrm{mg}$ of $\mathrm{E}_{2}$ in $5 \mathrm{ml}$ of $99.8 \%$ absolute ethanol, continuous infusion of $3 \mu \mathrm{g} / \mathrm{m} l(\mathrm{w} / \mathrm{v}) \mathrm{E}_{2}$ and $1 \%$ ethanol solution was administered at a rate of $10 \mathrm{ml} / \mathrm{min}$ for $7.5 \mathrm{hr}$. Cows were fed $3 \mathrm{hr}$ after the bolus injection, at which time the blood $\mathrm{E}_{2}$ concentration reaches the steady state, and the continuous infusion continued for another $4.5 \mathrm{hr}$ after feeding. Blood samples were taken via contralateral catheter before $E_{2}$ administration and at 1-hr intervals after the start of $E_{2}$ infusion for $7.5 \mathrm{hr}$. The catheter was flushed with heparinized saline after each sampling. Blood samples were collected into heparinized vacuum tubes and centrifuged at $1,700 \times g$ at $4{ }^{\circ} \mathrm{C}$ for 15 min to separate plasma, which was then stored frozen at $-20^{\circ} \mathrm{C}$ until $\mathrm{E}_{2}$ assay.

\section{Blood sampling}

Blood was also sampled from the coccygeal vein from Day 1 to Day 14 before morning feeding (8:00). Samples were collected into vacuum tubes with glass granules coated with a clot activator for serum collection, and into heparinized vacuum tubes for plasma collection. Serum separator tubes were left to clot, and plasma separator tubes were placed in a cooler box. Tubes were then centrifuged at $1,700 \times \mathrm{g}$ at $4^{\circ} \mathrm{C}$ for $15 \mathrm{~min}$, and serum and plasma samples were stored frozen at $-20^{\circ} \mathrm{C}$ until assay.

\section{Liver biopsy}

Liver biopsy was performed according to the method described by Nitanai et al. [8] after blood sampling on Day 14 . About $1.0 \mathrm{~g}$ of tissue was collected, immediately washed with sterile saline, and stored in liquid nitrogen until RNA extraction and UGT and triglyceride (TG) assays.

\section{Indocyanine green (ICG) clearance}

An ICG clearance test was performed on Day 13 before morning feeding, and the ICG half-life $\left(\mathrm{T}_{1 / 2}\right)$ value was determined according to the method described by Ono et al. [11].

\section{Hormone assay}

Plasma $\mathrm{P}_{4}$ concentrations were determined by enzyme immunoassay after diethylether extraction as described by Ono et al. [10]. The sensitivity of the assay was $0.16 \mathrm{ng} / \mathrm{ml}$, and the intra- and inter-assay CVs were 6.0 and $9.5 \%$, respectively. Plasma $\mathrm{E}_{2}$ concentrations were determined by a time-resolved fluorescent immunoassay after diethylether extraction as described by Ono et al. [10]. The sensitivity of the assay was $0.80 \mathrm{pg} / \mathrm{ml}$, and the intra- and inter-assay CVs were 5.0 and $10.7 \%$, respectively. Plasma IGF-1 concentration was determined using a commercial enzyme-linked immunosorbent assay kit (Human IGF-I Quantikine ELISA Kit, R\&D systems, Minneapolis, MN, U.S.A.). The sensitivity of the assay was $2 \mathrm{ng} / \mathrm{ml}$, and the intra- and inter-assay CVs were 1.1 and $2.1 \%$, respectively. 


\section{Serum chemistry}

Serum samples were submitted to the Health Sciences Research Institute (Kanagawa, Japan) for aspartate transaminase (AST), $\gamma$-glutamyl transpeptidase ( $\gamma$-GTP), total bilirubin (T-Bil), total cholesterol (T-Chol), non-esterified fatty acids (NEFA), glucose (Glu), and TG analysis.

\section{IGF-1 mRNA expression analysis}

Total RNA was extracted from liver tissue samples using Invitrogen's TRIZOL Reagent (Thermo Fisher Scientific, Waltham, MA, U.S.A.). RNA concentration was determined by spectrophotometer (NanoDrop 1000, Thermo Fisher Scientific). RNA extracts were stored at $-80^{\circ} \mathrm{C}$ until processed for cDNA synthesis.

RNA extracts were incubated with $2 \mu l$ of recombinant DNase I (RNase-free, Takara Bio, Shiga, Japan) and $0.5 \mu l$ of recombinant ribonuclease inhibitor (RNaseOUT, Takara Bio) in $10 \mu l$ of $10 \times$ DNase Buffer (RNase-free, Takara Bio) for 30 min at $37^{\circ} \mathrm{C}$ in a thermal cycler (MyiQ System, Bio-Rad, Hercules, CA, U.S.A.). cDNA synthesis was carried out on $500 \mathrm{ng}$ of total RNA per sample using an Applied Biosystems High-Capacity RNA-to-cDNA kit (Thermo Fisher Scientific) with the following cycling program: $5 \mathrm{~min}$ at $25^{\circ} \mathrm{C}$ (Step 1); $30 \mathrm{~min}$ at $42^{\circ} \mathrm{C}$ (Step 2); 5 min at $85^{\circ} \mathrm{C}$ (Step 3), and hold at $4{ }^{\circ} \mathrm{C}$ (Step 4).

Real-time PCR was performed using an Applied Biosystems 7500 Real-Time PCR System with a reaction mixture consisting of $25 \mu l$ of TaqMan Universal PCR Master Mix II, $1.25 \mu l$ of bovine IGF-1 probe (Bt03252280_m1, 5 pmol/ $\mu l$, TaqMan Gene Expression Assay), $1.25 \mu \mathrm{l}$ of $18 \mathrm{~S}$ ribosomal RNA probe (TaqMan Eukaryotic 18S rRNA Endogenous Control, VIC/MGB probe) (all from Thermo Fisher Scientific), $17.5 \mu \mathrm{l}$ of RNase-free water, and $25 \mathrm{ng}$ of cDNA. All PCR reactions were carried out in triplicate. As a negative control, RNase-free water was used instead of cDNA. 18S ribosomal RNA was assayed as a housekeeping gene.

The relative threshold cycle $(\mathrm{Ct})$ method was used for the quantification of RNA expression. Sample Ct values were normalized using the mean $\mathrm{Ct}$ value of housekeeping gene mRNA ( $\Delta \mathrm{Ct}=\mathrm{Sample} \mathrm{Ct}-\mathrm{Ct}$ of endogenous control). Three liver samples were processed per animal, and the mean relative expression of IGF-1 mRNA value was calculated.

\section{Hepatic UGT activity assay}

Microsome fractions were prepared as described by Kadokawa et al. [4], and UGT activity was determined using a UGT-Glo Assay (Promega, Madison, WI, U.S.A.). Microsomal membrane proteins were solubilized by incubating $25 \mu \mathrm{g} / \mathrm{m} l \mathrm{microsomes}$ in TES (pH 7.5) containing $0.01 \%$ cholic acid and $40 \mathrm{mM} \mathrm{MgCl}_{2}$ for $30 \mathrm{~min}$ on ice. The reaction was carried out for $30 \mathrm{~min}$ in Costar plates for fluorescent assay (Corning, NY, U.S.A.) with $20 \mu \mathrm{M}$ substrate, according to the kit protocol. A Wallac 1420 Multilabel Counter (Perkin Elmer, Waltham, MA, U.S.A.) was used to conduct the assay. UGT activity is expressed as \% substrate consumption after $30 \mathrm{~min}$ of reaction.

\section{Hepatic TG concentration}

An Adipogenesis Colorimetric/Fluorometric Assay Kit (BioVision, Milpitas, CA, U.S.A.) was used on weighed liver samples. The intra-assay and inter-assay variations were 3.1 and $6.3 \%$, respectively.

\section{Statistical analysis}

StatView 5.0 (SAS Institute Japan, Tokyo) was used to examine differences between the two groups, and the Mann-Whitney $U$ test was used to compare them. Repeated measures analysis of variance was used to compare changes in plasma $\mathrm{P}_{4}$ concentration during synchronization. Serum chemical values were compared in the groups between Day 1 and Day 14 using a paired $t$-test. Correlation between hepatic TG concentration and UGT activity was analyzed by Spearman's rank correlation coefficient. In the high-dose $\mathrm{E}_{2}$ administration study, the $\mathrm{E}_{2}$ concentration in one of the cows in the control group was higher than that in the other control individuals, and because it was rejected by the Grubbs-Smirnov rejection test, the mean value for the control group is shown as means \pm standard error of the mean (SEM) of three cows. All data are expressed as means \pm SEM. A level of $5 \%$ was considered significant.

\section{RESULTS}

\section{Body weight and BCS}

The body weight change rate was lower in the restricted feeding group than that in the control group from Day 2 to Day 14 $(P<0.05)$ (Fig. 1). The mean body weight decreased by $87.3 \mathrm{~kg}$ after 14 days of the restriction diet. The body weight of the control group did not change during the study period.

Similarly, the BCS change rate in the restricted feeding group was lower than that in the control group from Day 7 to Day 14 $(P<0.05)$ (Fig. 2). In restricted feeding group, the mean BCS on Day 14 was 0.312 points lower compared to that on Day 1 . There was no change in BCS in the control group.

\section{Plasma $E_{2}$ concentration}

Figure 3 shows mean plasma $\mathrm{E}_{2}$ concentrations after high-dose $\mathrm{E}_{2}$ administration on Day 14. The plasma $\mathrm{E}_{2}$ concentration in the restricted feeding group remained higher than that in the control group during $\mathrm{E}_{2}$ infusion $(P<0.05)$. 


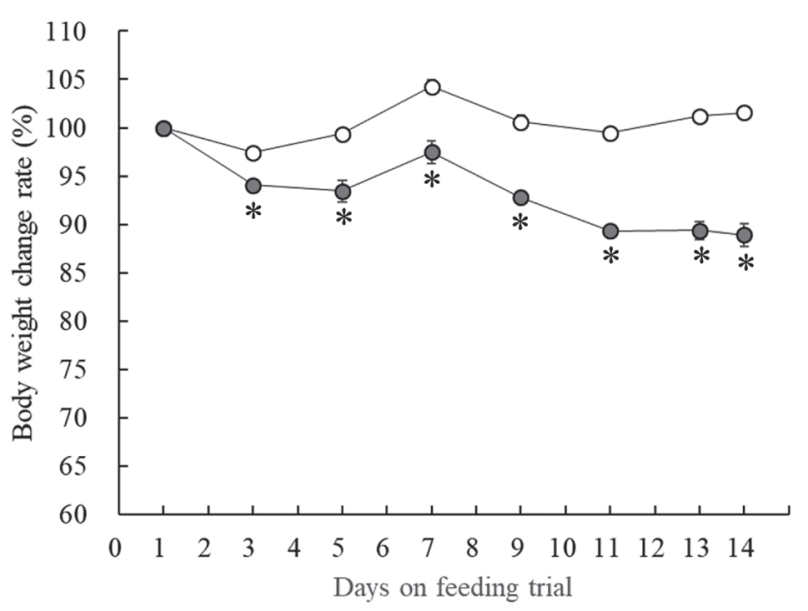

Fig. 1. Changes in body weight change rate during the study period. Cows were fed either a restricted feeding $(n=4$; filled circle) or control diet ( $\mathrm{n}=4$; open circle) for 14 days and received high-dose $E_{2}$ administration on Day 14. Error bars indicate SEM. *Significant difference between the two groups $(P<0.05)$

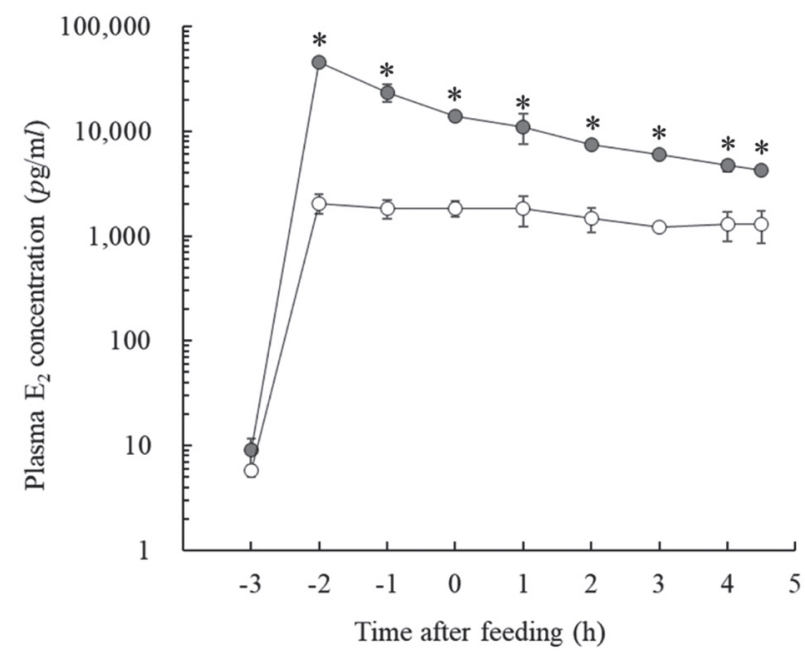

Fig. 3. Mean plasma estradiol-17 $\beta\left(\mathrm{E}_{2}\right)$ concentration on Day 14 during high-dose $\mathrm{E}_{2}$ administration. $\mathrm{E}_{2}$ infusion was started 3 $\mathrm{hr}$ before feeding and continued for another $4.5 \mathrm{hr}$ post-feeding. Cows were fed either a restricted feeding ( $n=4$; filled circle) or control diet ( $\mathrm{n}=3$; open circle) for 14 days before receiving high-dose $\mathrm{E}_{2}$ administration. Error bars, SEM. *Significant difference between the two groups $(P<0.05)$.

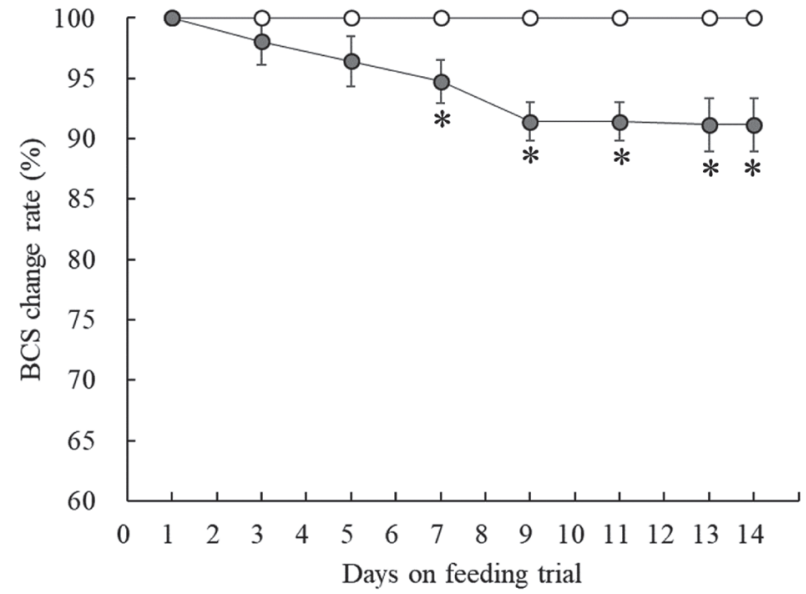

Fig. 2. Changes in body condition score (BCS) change rate during the study period. Cows were fed either a restricted feeding ( $n=4$; filled circle) or control diet ( $n=4$; open circle) for 14 days and received high-dose $E_{2}$ administration on Day 14. Error bars indicate SEM. * Significant difference between the two groups $(P<0.05)$.

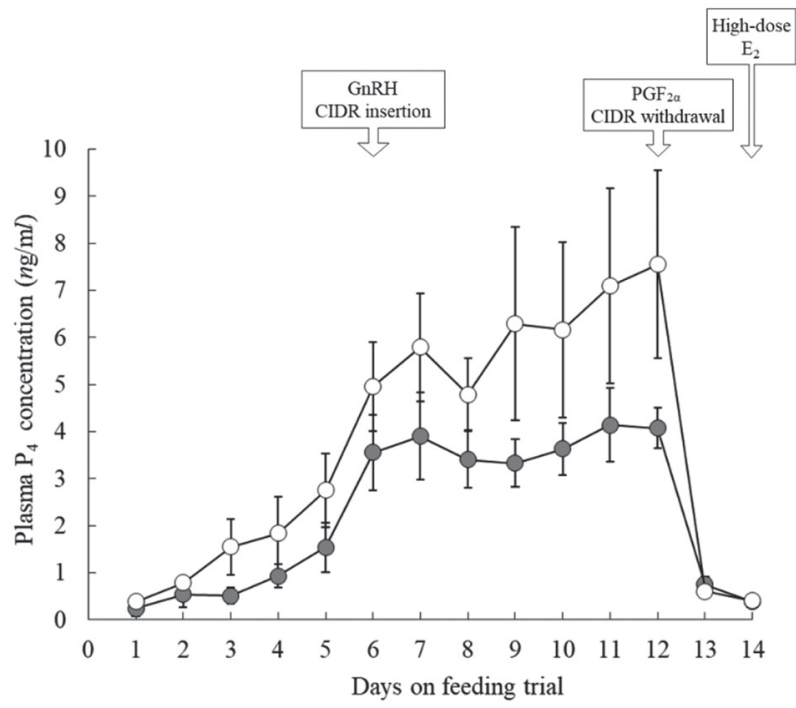

Fig. 4. Changes in plasma progesterone $\left(\mathrm{P}_{4}\right)$ concentration during the study period. Cows were fed either a restricted feeding $(n=4$; filled circle) or control diet $(n=4$; open circle) for 14 days and received high-dose $\mathrm{E}_{2}$ administration on Day 14. Error bars indicate SEM. $E_{2}$, estradiol-17 $\beta$; GnRH, gonadotropinreleasing hormone; $\mathrm{PGF}_{2 \alpha}$, prostaglandin $\mathrm{F}_{2 \alpha}$.

\section{Plasma $\mathrm{P}_{4}$ concentration}

Plasma $\mathrm{P}_{4}$ concentrations during the study period are shown in Fig. 4. Changes in $\mathrm{P}_{4}$ concentrations were different between the two groups $(P<0.05)$.

\section{Serum chemistry}

Serum chemical values on Day 1 and Day 14 are shown in Table 1. No significant differences were observed in the control group between Day 1 and Day 14. In contrast, the restricted feeding group showed higher NEFA and T-Bil on Day 14 than those on Day $1(P<0.05)$. 
Table 1. Serum chemical values before (Day 1) and after the start of feeding trial (Day 14)

\begin{tabular}{lccccc}
\hline & \multicolumn{2}{c}{ Control $(\mathrm{n}=4)$} & & \multicolumn{2}{c}{ Restricted feeding $(\mathrm{n}=4)$} \\
\cline { 2 - 3 } \cline { 5 - 6 } & Day 1 & Day 14 & & Day 1 & Day 14 \\
\hline AST (IU $/ l)$ & $52.5 \pm 4.7$ & $47.5 \pm 6.8$ & & $61 \pm 7.3$ & $50.5 \pm 3.3$ \\
$\gamma$-GTP $(\mathrm{IU} / l)$ & $28.3 \pm 1.9$ & $27.3 \pm 1.7$ & & $28 \pm 2.0$ & $26.3 \pm 1.9$ \\
T-Bil $(\mathrm{mg} / \mathrm{d} l)$ & $0.2 \pm 0.0$ & $0.1 \pm 0.0$ & & $\left.0.2 \pm 0.0^{\mathrm{a}}\right)$ & $\left.0.3 \pm 0.0^{\mathrm{b}}\right)$ \\
$\mathrm{TG}(\mathrm{mg} / \mathrm{d} l)$ & $23.3 \pm 3.7$ & $13.8 \pm 3.1$ & & $13.8 \pm 2.6$ & $8.5 \pm 1.2$ \\
T-Chol $(\mathrm{mg} / \mathrm{d} l)$ & $88.0 \pm 8.7$ & $82.8 \pm 7.6$ & & $64.0 \pm 8.4$ & $64.8 \pm 7.5$ \\
NEFA $(\mu \mathrm{Eq} / l)$ & $225.0 \pm 96.7$ & $230.0 \pm 89.8$ & & $\left.357.5 \pm 104.1^{\mathrm{a}}\right)$ & $700.0 \pm 57.2^{\mathrm{b})}$ \\
Glu $(\mathrm{mg} / \mathrm{d} l)$ & $66.0 \pm 1.6$ & $71.0 \pm 1.2$ & & $77.3 \pm 4.1$ & $83.3 \pm 4.4$ \\
\hline
\end{tabular}

Data are expressed as mean \pm SEM. Values with different letters $(\mathrm{a}, \mathrm{b})$ are significantly different $(P<0.05)$. AST, aspartate transaminase; g-GTP, g-glutamyl transpeptidase; Glu, glucose; NEFA, non-esterified fatty acids; T-Bil, total bilirubin; T-Chol, total cholesterol; TG, triglyceride.

Table 2. Comparison of liver function profiles

\begin{tabular}{lcc}
\hline & Control $(\mathrm{n}=4)$ & Restricted feeding $(\mathrm{n}=4)$ \\
\hline ICG T $_{1 / 2}(\mathrm{~min})$ & $\left.4.3 \pm 0.4^{\mathrm{a}}\right)$ & $10.5 \pm 3^{\mathrm{b})}$ \\
Hepatic TG concentration $(\mathrm{mg} / \mathrm{g})$ & $38.6 \pm 7.4^{\mathrm{a}}$ & $\left.63.3 \pm 6.1^{\mathrm{b}}\right)$ \\
Hepatic UGT activity $(\%)$ & $20.4 \pm 2.4^{\mathrm{a}}$ & $12.9 \pm 1.4^{\mathrm{b}}$ \\
Plasma IGF-1 concentration $(\mathrm{ng} / \mathrm{m} /)$ & $96.2 \pm 8.7$ & $98.1 \pm 16.7$ \\
Hepatic IGF-1 mRNA expression (arbitrary units) & $1.8 \pm 0.2$ & $1.8 \pm 0.2$ \\
\hline
\end{tabular}

Data are expressed as mean \pm SEM. Values with different letters $(a, b)$ are significantly different $(P<0.05)$. ICG, indocyanine green; TG, triglyceride; UGT, uridine diphosphate glucuronosyltransferase; IGF-1, insulin-like growth factor-1.

\section{Liver function profiles}

Liver function profiles are shown in Table 2. The ICG $\mathrm{T}_{1 / 2}$ value on Day 13 was longer in the restricted feeding group $(10.5 \pm 3.0 \mathrm{~min})$ than in the control group $(4.3 \pm 0.4 \mathrm{~min})(P<0.05)$. The mean hepatic TG concentration on Day 14 was $63.3 \pm 6.1 \mathrm{mg} / \mathrm{g}$ of wet weight in the restricted feeding group and was higher compared to $38.6 \pm 7.4 \mathrm{mg} / \mathrm{g}$ of wet weight in the control group $(P<0.05)$. The hepatic UGT activity on Day 14 is shown in Fig. 5. After 2 weeks of restricted feeding, the hepatic UGT activity $(12.9 \pm 1.4 \%)$ was lower than that of the control group $(20.4 \pm 2.4 \%)(P<0.05)$. The hepatic UGT activity was negatively correlated to the hepatic TG concentration $(\rho=-0.905, P<0.05)$ (Fig. 5).

The plasma IGF-1 concentration was $121.0 \pm 21.5 \mathrm{ng} / \mathrm{m} l$ and $110.5 \pm$ $7.5 \mathrm{ng} / \mathrm{m} l$ on Day 1 and $98.1 \pm 16.7 \mathrm{ng} / \mathrm{m} l$ and $96.2 \pm 8.7 \mathrm{ng} / \mathrm{m} l$ on Day 14 in the restricted feeding group and control group, respectively. No significant difference was found between the groups. The hepatic IGF-1 mRNA expression was $1.8 \pm 0.4$ in the restricted feeding group and 1.8 \pm 0.2 in the control group. These values were not significantly different.

\section{DISCUSSION}

In this study, we investigated the effect of restriction feeding on liver estrogen metabolism in non-lactating cows. Our results indicate that ICG $\mathrm{t}_{1 / 2}$ was prolonged by $30 \% \mathrm{TDN}$ restricted feeding for 13 days, and increased liver TG concentration and decreased liver UGT activity were caused by this restriction over 14 days. As expected, the 2-week feeding restriction resulted in body weight reduction $(87.3 \mathrm{~kg})$ and BCS reduction $(0.312$ points). In our study, the plasma NEFA and T-Bil concentrations increased significantly over the 14 days of restriction feeding, indicating that lipomobilization had occurred. However, the restriction feeding did not cause altered serum chemistry values, indicating liver dysfunction or altered plasma IGF-1 and hepatic IGF-1 expression during the study period.

During the high-dose $\mathrm{E}_{2}$ administration, the restricted feeding group showed continuously higher $\mathrm{E}_{2}$ concentrations than the control group. These findings are consistent with a previous report on ovariectomized ewes [15], in which feeding restriction resulted in body weight reduction of 10 to $15 \%$ over 7 weeks and consistently higher serum $E_{2}$ after high-dose $E_{2}$ administration 
$(0.31 \mu \mathrm{g} / 50 \mathrm{~kg} / \mathrm{hr})$ compared with ewes on a maintenance diet.

In wether lambs, energy restriction also results in decreased liver weight [19], which seems to precede body weight reduction [9]. It was also reported that hepatic metabolism of volatile fatty acids was decreased by $70 \%$ in dairy cows after six days of fasting, and that even though the hepatic metabolic rate doubled after the reintroduction of feeding 3 days later, it remained $32 \%$ lower than that of pre-fasting levels [5]. We previously reported that the ICG $\mathrm{t}_{1 / 2} 3 \mathrm{hr}$ after feeding was shorter than the pre-feeding value, and that 4-day fasting prolonged ICG $t_{1 / 2}$ in dry cows [11]. This finding suggests that ICG clearance is not only affected by impaired liver function, but also by gastrointestinal blood flow and hepatic blood flow due to the presence or absence of food intake. In the present study, high levels of serum NEFA and liver TG concentrations, and decreased hepatic UGT metabolism in the restricted group suggest a decreased metabolic capacity of the liver. However, since AST was in the normal range and the plasma IGF-1 concentration and hepatic IGF-1 mRNA expression level had not decreased, we concluded that the impairment of liver function was mild. This suggests that the prolonged ICG clearance time in the present study is caused by a slightly impaired liver function and a decrease in liver blood flow due to restricted feeding. Plasma $\mathrm{E}_{2}$ remained higher in the restricted feeding group after high-dose $E_{2}$ administration, likely due to the decreased hepatic metabolism since $85 \%$ of $E_{2}$ is metabolized in the liver [12].

We previously reported that in dry cows 4-day fasting leads to reduced hepatic steroid hormone metabolism through accumulation of fat in the liver, which causes high peripheral steroid hormone concentrations [10]. In contrast, in the current study, plasma $\mathrm{P}_{4}$ concentration was consistently lower in the restricted feeding group. This is probably because of poor development of the corpus luteum due to dietary restriction, as reported in heifers that were fed $62 \%$ of the TDN requirement [2]. However, it is also possible that $\mathrm{P}_{4}$ absorption from the intravaginally-placed CIDR was lower in these cows due to the reduced blood flow associated with restrictive feeding.

Together, the results presented in this report suggest that 2-week restricted feeding in dry dairy cows leads to the accumulation of TG and decreased liver blood flow, altering liver $\mathrm{E}_{2}$ metabolism by UGT without significantly impacting the synthesis and secretion of IGF-1.

\section{REFERENCES}

1. Ferguson, J. D., Galligan, D. T. and Thomsen, N. 1994. Principal descriptors of body condition score in Holstein cows. J. Dairy Sci. 77: $2695-2703$. [Medline] [CrossRef]

2. Gombe, S. and Hansel, W. 1973. Plasma luteinizing hormone (LH) and progesterone levels in heifers on restricted energy intakes. J. Anim. Sci. 37: 728-733. [Medline] [CrossRef]

3. Honour, J. W. 1984. Biliary excretion and enterohepatic circulation. pp. 383-404. In: Biochemistry of Steroid Hormones, 2nd ed. (Makin, H. L. J. ed.), Blackwell Scientific publications, Oxford.

4. Kadokawa, H., Matsumoto, J. and Yokota, H. 2007. In vitro glucuronidation of estradiol-17ß by microsomes prepared using liver biopsy specimens from dairy cows. J. Vet. Med. Sci. 69: 557-559. [Medline] [CrossRef]

5. Lomax, M. A. and Baird, G. D. 1983. Blood flow and nutrient exchange across the liver and gut of the dairy cow. Effects of lactation and fasting. Br. J. Nutr. 49: 481-496. [Medline] [CrossRef]

6. McKerns, K. W. 1976.Catabolism and inactivation of steroid hormones by the liver and kidney. pp. 119-131. In: Steroid Hormones and Metabolism (in Japanese). (Shida, K., Tadokoro, S. and Ito, Z. trans.), Iwasaki Academic Publisher, Tokyo.

7. National Agriculture and Food Research Organization. 2006. Japanese feeding standard for dairy cattle (in Japanese), Japanese livestock industry association, Tokyo.

8. Nitanai, A., Oikawa, S., Sasaki, K., Suzuki, M., Sakata, M., Kurosawa, T. and Satoh, H. 2000. Association of hepatic lipidosis with body weight and serum biochemical variables in fasted cows. Vet. Biochem. 37: 79-85 (in Japanese).

9. Nozière, P. and Doreau, M. 2001. Effect of short-term underfeeding on weight of splanchnic organs in ewes. Arch. Tierernahr. 54: 305-314. [Medline] [CrossRef]

10. Ono, M., Ohtaki, T., Tanemura, K., Ishii, M., Watanabe, G., Taya, K. and Tsumagari, S. 2011. Effect of short-term fasting on hepatic steroid hormone metabolism in cows. J. Vet. Med. Sci. 73: 1145-1149. [Medline] [CrossRef]

11. Ono, M., Ohtaki, T., Tanemura, K., Ishii, M. and Tsumagari, S. 2011. Relationship between indocyanine green clearance test and feed intake and impaired hepatic function in dairy cows. J. Vet. Med. Sci. 73: 1497-1499. [Medline] [CrossRef]

12. Pardridge, W. M. 1981. Transport of protein-bound hormones into tissues in vivo. Endocr. Rev. 2: 103-123. [Medline] [CrossRef]

13. Parr, R. A., Davis, I. F., Miles, M. A. and Squires, T. J. 1993 . Feed intake affects metabolic clearance rate of progesterone in sheep. Res. Vet. Sci. 55: 306-310. [Medline] [CrossRef]

14. Parr, R. A., Davis, I. F., Miles, M. A. and Squires, T. J. 1993b. Liver blood flow and metabolic clearance rate of progesterone in sheep. Res. Vet. Sci. 55: 311-316. [Medline] [CrossRef]

15. Renquist, B. J., Calvert, C. C., Adams, B. M. and Adams, T. E. 2008. Circulating estradiol suppresses luteinizing hormone pulse frequency during dietary restriction. Domest. Anim. Endocrinol. 34: 301-310. [Medline] [CrossRef]

16. Rhoads, R. P., Kim, J. W., Van Amburgh, M. E., Ehrhardt, R. A., Frank, S. J. and Boisclair, Y. R. 2007. Effect of nutrition on the GH responsiveness of liver and adipose tissue in dairy cows. J. Endocrinol. 195: 49-58. [Medline] [CrossRef]

17. Sangsritavong, S., Combs, D. K., Sartori, R., Armentano, L. E. and Wiltbank, M. C. 2002. High feed intake increases liver blood flow and metabolism of progesterone and estradiol-17ß in dairy cattle. J. Dairy Sci. 85: 2831-2842. [Medline] [CrossRef]

18. Wieghart, M., Slepetis, R., Elliot, J. M. and Smith, D. F. 1986. Glucose absorption and hepatic gluconeogenesis in dairy cows fed diets varying in forage content. J. Nutr. 116: 839-850. [Medline] [CrossRef]

19. Wester, T. J., Britton, R. A., Klopfenstein, T. J., Ham, G. A., Hickok, D. T. and Krehbiel, C. R. 1995. Differential effects of plane of protein or energy nutrition on visceral organs and hormones in lambs. J. Anim. Sci. 73: 1674-1688. [Medline] [CrossRef]

20. Wiltbank, M., Lopez, H., Sartori, R., Sangsritavong, S. and Gümen, A. 2006. Changes in reproductive physiology of lactating dairy cows due to elevated steroid metabolism. Theriogenology 65: 17-29. [Medline] [CrossRef]

21. Zulu, V. C., Nakao, T. and Sawamukai, Y. 2002. Insulin-like growth factor-I as a possible hormonal mediator of nutritional regulation of reproduction in cattle. J. Vet. Med. Sci. 64: 657-665. [Medline] [CrossRef] 